Published in: Europe's Income, Wealth, Consumption, and Inequality, 2021, Chapter

\title{
Europe's migration experience and its effects on economic inequality
}

Martin Guzi ID / Masaryk University, CELSI and IZA

Martin Kahanec D / Central European University, University of Economics in Bratislava, CELSI, and GLO

Magdalena M. Ulceluse / University of Groningen, CELSI and GLO 


\section{Europe's migration experience and its effects on economic inequality}

\section{Abstract}

This chapter provides the historical context for the past half-century in Europe focusing specifically on the link between migration and economic development and inequality. The literature review suggests that there are several channels through which migration affects economic inequality between countries in one or the other direction. The net effects are an open empirical question and are likely to depend on the economic, demographic and institutional and policy contexts; sources, types and selectivity of migration, as well as responses of the receiving societies as well as migrants themselves. We undertake an empirical analysis and find that immigration has contributed to reducing inequality within the $25 \mathrm{EU}$ countries over the 2003-2017 period. As the EU attracted relatively highly qualified immigrants throughout this period, our results are consistent with the ameliorating effect of skilled migration on within-country inequality, as predicted by theory.

Masaryk University

Faculty of Economics and Administration

Authors:

Martin Guzi (ORCID: 0000-0001-9936-3175) / / Masaryk University, CELSI and IZA

Martin Kahanec (ORCID: 0000-0003-4397-3083) / Central European University, University of Economics in Bratislava, CELSI, and GLO

Magdalena M. Ulceluse / University of Groningen, CELSI and GLO

Contact: KahanecM@spp.ceu.edu

Creation date: 2021-02

Revision date: 2023-01

Keywords: immigration, inequality, labour mobility, income distribution, EU enlargement

JEL classification: D31, D60, O15

Citation:

Guzi, M., Kahanec, M., Ulceluse, M.M. (2021). Europe's migration experience and its effects on economic inequality. MUNI ECON Working Paper n. 2021-05. Brno: Masaryk University. https://doi.org/10.5817/WP_MUNI_ECON_2021-05 


\title{
Europe's migration experience and its effects on economic inequality ${ }^{1}$
}

\author{
Martin Guzi \\ Masaryk University, CELSI and IZA \\ Martin Kahanec ${ }^{2}$ \\ Central European University, University of Economics in Bratislava, CELSI, and GLO \\ Magdalena M. Ulceluse \\ University of Groningen, CELSI and GLO
}

\begin{abstract}
This chapter provides the historical context for the past half-century in Europe focusing specifically on the link between migration and economic development and inequality. The literature review suggests that there are several channels through which migration affects economic inequality between countries in one or the other direction. The net effects are an open empirical question and are likely to depend on the economic, demographic and institutional and policy contexts; sources, types and selectivity of migration, as well as responses of the receiving societies as well as migrants themselves. We undertake an empirical analysis and find that immigration has contributed to reducing inequality within the 25 EU countries over the 20032017 period. As the EU attracted relatively highly qualified immigrants throughout this period, our results are consistent with the ameliorating effect of skilled migration on within-country inequality, as predicted by theory.
\end{abstract}

JEL codes: D31; D60; O15

Keywords: immigration, inequality, labour mobility, income distribution, EU enlargement

\footnotetext{
${ }^{1}$ This is a draft of a chapter that has been accepted for publication by Oxford University Press in the book Europe's migration experience and its effects on economic inequality edited by G. Fischer and R. Strauss due for publication in 2021 (link).

Citation: Guzi, M., Kahanec, M., Ulceluse, M. (2021). Europe's migration experience and its effects on economic inequality. In G. Fischer and R. Strauss (eds.), Europe's Income, Wealth, Consumption, and Inequality (pp. 488-516). Oxford: Oxford University Press.

${ }^{2}$ Corresponding author: Martin Kahanec, School of Public Policy, Central European University, Nádor u. 11, H-1051 Budapest, Hungary, Email: KahanecM@spp.ceu.edu.
} 


\section{Introduction}

Economic inequality refers to the disparity of wealth, income, consumption or other economic variables within or across societies. A certain degree of economic inequality may provide incentives to work and invest in human or social capital and stimulate growth and social progress (Grusky, 2018). However, the literature also shows that high levels of economic inequality within countries hinder productivity and contribute to social problems, including health problems such as obesity, poor educational performance, or violence (Wilkinson and Pickett, 2009; Ravallion, 2014; Chetty et al., 2016). The role of the government has been emphasised in reducing economic inequality and encouraging upward intergenerational social mobility.

Among the various demographic, economic, social, institutional, and political variables affecting economic inequality (Acemoglu et al., 2001; Milanovic, 2011; Picketty, 2014), migration stands out as one that has recently received considerable attention in the political discourse in Europe, but also the United States and other parts of the world. One of the reasons for this attention is that migration changes the composition of the sending and receiving populations, which may affect the competition for jobs and welfare and create winners and losers in the sending and receiving regions, with consequences for economic inequality.

The extent to which economic inequality in the receiving and sending countries is affected by migration depends on a range of factors. One of them is the selection of migrants: who goes, where to, and when (e.g. whether the migrants are men or women, young or old, skilled or unskilled, or wealthy or poor; whether they go to booming or declining regions, occupations or industries; and whether they come in good or bad times, and how long they plan to stay). Migration may affect wages or employment in sending and receiving countries as some migrants send remittances to their families left behind. The response of the stayers and natives matters as they may invest in their human capital, change their occupation, and they themselves may move. Migration may also affect governmental policies, such as redistributive policies and access to welfare. Migration may result in technological transfer, trade, or capital flows. The effects of migration also depend on how immigrants integrate in the receiving societies and how the sending and receiving societies adjust to migration.

Understanding the relationships between migration and economic inequality is not only instrumental for the design of migration, economic and welfare policies, but also for the understanding of the current political and public debates on migration in the European Union (EU). In this effort, it is important to take into account the idiosyncrasies of migration patterns and the changing policy contexts that have characterised the EU over the past decades. 
The COVID-19 pandemics that hit Europe and the world in early 2020, causing many fatalities and a severe health crisis in a number of countries, provides a rare opportunity to study the nexus between migration and inequality, as severe restrictions on international migration have been imposed in Europe and elsewhere in response to it. The pandemics provides a natural experiment to enable researchers to identify causal impacts of migration (or the lack of it) on economic inequality. As the data were not yet available when this chapter went to print, however, this opportunity will remain for future research.

This chapter provides the historical context for the past half-century in Europe and the EU, focusing specifically on the link between migration and economic inequality. It reviews the literature about the migration-inequality nexus from the perspective of both intra- and within-country economic inequality, and it studies the effect of migration on income inequality in receiving societies in a longitudinal analysis of 25 EU countries covering the 2003-2017 period. We document multiple effects of migration on economic inequality within and between countries and suggest that immigration contributes to reducing inequality in receiving countries. Section 2 provides the historical context in Europe and the EU; Section 3 presents a conceptual framework of the migration-inequality nexus recognising within- and between-country inequality; Section 4 empirically analyses this relationship; and Section 5 concludes.

\section{Migration and inequality in the $\mathbf{E U}$}

Human migration has always been an integral part of the European experience. It has affected and responded to the economic, social, and political situations of European societies. The modern era of European migration begins shortly after World War II, when the post-war recovery and strong economic growth resulted in demand for labour that could no longer be satisfied domestically. Countries with a colonial history, such as Belgium, France, the Netherlands, and the United Kingdom, were able to draw on a vast supply of low-skilled labour from their former colonies (Hansen, 2003). The United Kingdom experienced immigration primarily from India, Pakistan, Kenya, and Malaysia; France from Algeria, and later Tunisia and Morocco; Belgium from Congo; and the Netherlands from Indonesia (Van Mol and de Valk, 2016). Several countries, most notably Germany, but also Austria, Belgium, Denmark, Sweden, Switzerland, and to a lesser degree France and the Netherlands, implemented guest worker programmes aimed at providing a supply of much-needed labour. For example, the German government negotiated guest worker programmes with Italy (1955), Greece and Spain (1960), Turkey (1961), Morocco (1963), Portugal (1964), Tunisia (1965), and Yugoslavia 
(1968) (Hansen, 2003). During this time, migration flows were strongly affected by income inequalities and differences in economic development between the sending and receiving countries. Countries with a flourishing economy, strong labour demand, and high wage levels became attractive for immigrants from countries with high unemployment rates, low wage levels, and stagnating economies (Fassmann and Munz, 1992). Within the source countries, most migrant workers originated from poor agricultural regions with weak labour demand, such as northern Portugal, western Spain, southern Italy, and northern Greece (Bade, 2003). A comparison of gross domestic product (GDP) per capita (in current US dollars) in 1960 documents significant economic inequality between sending and receiving countries. Per capita GDP in the sending countries ranged from US\$164 in Morocco; US\$360 in Portugal; US\$396 in Spain; US\$533 in Greece; and US\$804 in Italy, compared to US\$1,787 in Switzerland; US $\$ 1,983$ in Sweden; US\$1,068 in the Netherlands; US\$1,380 in the UK; and US\$1,338 in France, representing some of the key receiving countries (World Bank, 2018).

By the early 1970s, 2.0 million foreign workers and 690 thousand dependants had entered France, while 2.6 million workers had entered Germany (Castles and Miller, 1998). Migration during this period had mostly positive effects on both sending and receiving countries. For receiving countries, it provided a much-needed labour force to sustain their economic growth, while for sending countries it provided relief from unemployment and strengthened income through remittances (Zimmermann, 2005). In the Mediterranean region, emigration helped to alleviate imbalances and excess supply in the labour market as the region was characterised by low productivity and income and high unemployment (Page Moch, 2003). In Turkey, for example, remittances became a vital source of income (Barou, 2006).

Increasingly large numbers of immigrants and the realisation that immigration was becoming permanent, along with the 1973 oil crisis, prompted the receiving countries to stop or severely restrict immigration. Active labour recruitment was effectively stopped in all receiving countries in the early 1970 s. ${ }^{3}$ Despite this, South-North migration continued through family reunification and later through family formation, particularly among immigrants from non-EU countries, such as Turkey or Morocco. Although guest worker programmes were intended to foster temporary migration, return migration was slow (Zaiceva and Zimmermann, 2008). Nevertheless, the abrupt discontinuation of guest worker programmes stymied migration flows in Europe, and the resulting sharp decline in remittances adversely affected or even economically destabilised some of the sending countries, e.g. Turkey (Barou, 2006).

\footnotetext{
${ }^{3}$ The guest worker programmes were discontinued in 1970 in Switzerland, in 1971 in the UK, in 1972 in France, in 1973 in Germany and in 1974 in the Benelux countries (Van Mol and Helga de Valk, 2016; Hansen, 2004).
} 
In the aftermath of the first oil crisis of the early 1970s, Italy, Greece, Spain and Portugal experienced return migration from former labour-recruiting countries; and by the 1980s, they had turned into receiving countries for immigration from Africa, Asia and Latin America (Castles and Miller, 1998). Several factors contributed to this transition from emigration to immigration countries. First, Italy, Spain and Greece experienced robust economic growth, which, coupled with a population decline, triggered labour shortages. In addition, restrictive immigration policies introduced by Germany and France diverted migrant flows to the emerging southern economies, where migrants found demand for labour and relatively open immigration policies.

Contemporaneously, the level of economic inequality between sending and receiving countries decreased significantly, as evidenced by smaller differences between the levels of GDP per capita in 1988 and those reported earlier for 1960: US\$15,027 in Portugal; US\$18,972 in Greece; US\$20,703 in Spain; and US\$29,294 in Italy, compared to US\$27,925 in the UK; US\$30,658 in France; US\$33,040 in the Netherlands; and US\$36,795 in Sweden. The highest income in 1980 was 2.4 times higher than the lowest income (Sweden vs. Portugal), down from 5.5 times in 1960 .

The beginning of the 1990s gave way to new patterns of migration in Europe (Zimmermann, 2005; Van Mol and de Valk, 2016). The fall of the Iron Curtain triggered a wave of East-West migration from Eastern Europe, much of it ethnically driven (e.g., ethnic Germans from Poland and Romania moving to Germany) (OECD, 2001). Ten countries joined the EU in 2004 (Cyprus, Czechia, Estonia, Hungary, Latvia, Lithuania, Malta, Poland, Slovakia, and Slovenia), followed by Bulgaria and Romania in 2007, and Croatia in 2013. These enlargements extended the right of free movement of workers to more than 100 million new EU citizens and led to significant East-West and East-South mobility within the EU (Kahanec and Zimmermann 2010, 2016; Kahanec, Pytlikova and Zimmermann, 2016). ${ }^{4}$ An additional migration stream of asylum seekers and refugees was driven by conflicts in the former Yugoslavia in the 1990s, Afghanistan and Iraq in the 2000s, and Syria in the 2010s.

As with the previous migration patterns, East-West and East-South European migration after 2000 was motivated by deep economic disparities between the sending and receiving countries. In 2004, Poland's GDP per capita was US\$5,632, compared to US\$38,813 in the United Kingdom and US\$49,678 in Ireland, two of the main destinations for Polish workers. Similarly, in 2007 Romania's GDP per capita of US\$8,061 was substantially below the levels

\footnotetext{
${ }^{4}$ The so-called transitional arrangements enabled the incumbent EU member states to apply domestic legislation and delay the full implementation of free movement of workers vis-à-vis the new EU citizens for up to 7 years.
} 
in Spain (US\$32,460) and Italy (US\$38,237), the main migration destinations for Romanians. EU enlargement has triggered large flows of migrants from the member states that joined the EU in 2004 and 2007 to the incumbent member states, increasing the total population of citizens from these new members to the old members from about 2.0 million in 2004 to 5.0 million in 2009; these flows gradually declined and stabilized after this period (Kahanec and Zimmermann, 2016).

The economic and financial crisis of the late 2000s, also called the Great Recession, affected some of the peripheral countries more than the rest of the EU. Figures 1 and 2 show GDP per capita and unemployment rate trends in the EU countries. Whereas some countries experienced deep recessions, followed by sluggish (e.g., Greece and Italy) or more rapid (e.g., Cyprus, Portugal, and Spain) recovery, a number of countries were affected less dramatically and went through just a short period of contraction, before returning on the same trend of GDP growth (Germany, Lithuania, Slovakia). Poland was the only EU member state that did not record a recession during this period. These trends in GDP per capita were, usually with some delay, reflected in the patterns of unemployment in across the EU (Figure 2).

A new migration wave emerged from countries such as Greece, Ireland, Italy, Portugal, and Spain (Van Mol and de Valk, 2016). Spain, Ireland, and Greece experienced negative net migration, as the size of the emigration flows exceeded that of immigration between 2009/20102015 (Eurostat, 2018). During this period, migrants' countries of origin became more varied and intra-EU migration intensified (Eurostat, 2018). A notable development throughout this period is the creation of a dichotomy between EU and non-EU immigration, with each type governed by different sets of policies.

The European Union's so- called 'migration crisis' of the mid-2010s deepened the existing cleavages within and between its member states with profound socio-economic and political consequences. The arrival of an unprecedented number of asylum seekers - more than 1.2 million applications in Germany, 206 thousand in Italy, 200 thousand in Hungary, and 191 thousand in Sweden in 2015-2016 (Eurostat, 2019b) - led to a polarized political climate, with national interests trumping the efforts for a common EU response. The burden of receiving and processing asylum requests and caring for refugees was unevenly distributed across member states, often with the resource-strained countries like Greece, Italy, or Bulgaria taking a heavier share of the burden. Immigration became the political and policy issue of the time, not only in traditional immigration countries, but in new member states, like Hungary, Poland, Czechia or Slovakia (Taggart and Szczerbiak, 2018). These states were reluctant to admit refugees under the EU re-allocation scheme, which intended to redistribute refugees from those of first entrance 
to member states with comparatively low numbers of refugees. By contrast, Germany and Sweden pledged to take in a significant number of refugees under relatively generous asylum policies.

The migration crisis came on the heels of the economic and financial crisis of 2008, which had already decreased in the standard of living of many EU citizens, particularly in Southern European countries, and triggered significant intra-EU migration flows even before the European migration crisis (Trenz and Triandafyllidou, 2017; Recchi and Salamońska, 2015). Building up on a growing discontent with policies and the response to the migration crisis in particular, populist parties acceded to political significance in many countries across Europe. In Germany, the Alternative für Deutschland (AfD) gained popularity almost exclusively based on anti-immigration rhetoric. Similar parties include Vlaams Belang in Belgium, the Finns Party in Finland, Front National in France, Fidesz and Jobbik in Hungary, Northern League in Italy, Party for Freedom in the Netherlands, and Law and Justice in Poland. Lastly, migration became the defining issue in the Leave campaign leading up to the Brexit vote in 2016. Devised as a movement to regain national sovereignty and in which seizing control over migration played a major role, the Leave campaign came on the eve of a migration crisis that created the image of an EU not capable of handling the situation (Outhwaite, 2019). The recent literature explains that the UK referendum on Brexit was driven by a mix of economic determinants (Arnorsson and Zoega, 2018) including the impact of fiscal austerity (Becker et al., 2017; Alabrese et al., 2018). Other authors argue that subjective sentimental factors were more important than objective determinants (Eichengreen, Mari, and Thwaites, 2018). In any case, this surge in the popularity and activity of far-right populist parties has signified heated and polarized debates over immigration within and across the EU states, and undermined the efforts to respond to the migration crisis and, more generally, to labour mobility.

However, the increasingly anti-immigration political discourse across Europe does not seem to have translated into a seismic shift in citizens' attitudes towards migration. Rather, these attitudes have remained fairly constant over the past decade, even becoming somewhat more positive in some cases. A comparison between the 2002 and 2014 rounds of the European Social Survey (ESS) reveals that in only two countries - Austria and Czechia - have the attitudes towards immigration become slightly more negative (Heath and Richards, 2016). Overall, the Nordic countries tended to express more positive attitudes towards immigration, while eastern European countries more negative (Heath and Richards, 2016). The comparison of attitudes towards EU and non-EU immigration between 2014 and 2018 confirm these trends. 
While the share of very negative attitudes towards non-EU immigrants seem to have decreased over this period, which encompasses the 2015 migration crisis, the share of respondents with a positive attitude has increased. Concerning intra-EU migration, about half of the respondents have a fairly positive attitude, up from about $40 \%$ in 2014, with a corresponding decrease in negative attitudes over the same time period. The relative stability of attitudes to migration over time and across countries might just reflect the inertia at the individual and societal level regarding preferences, social norms, or attitudes. However, it may also be due to the balancing out of opposing forces, cancelling out some of the positive and negative effects on attitudes towards immigrants. 
Figure 1 GDP per capita trends in the EU
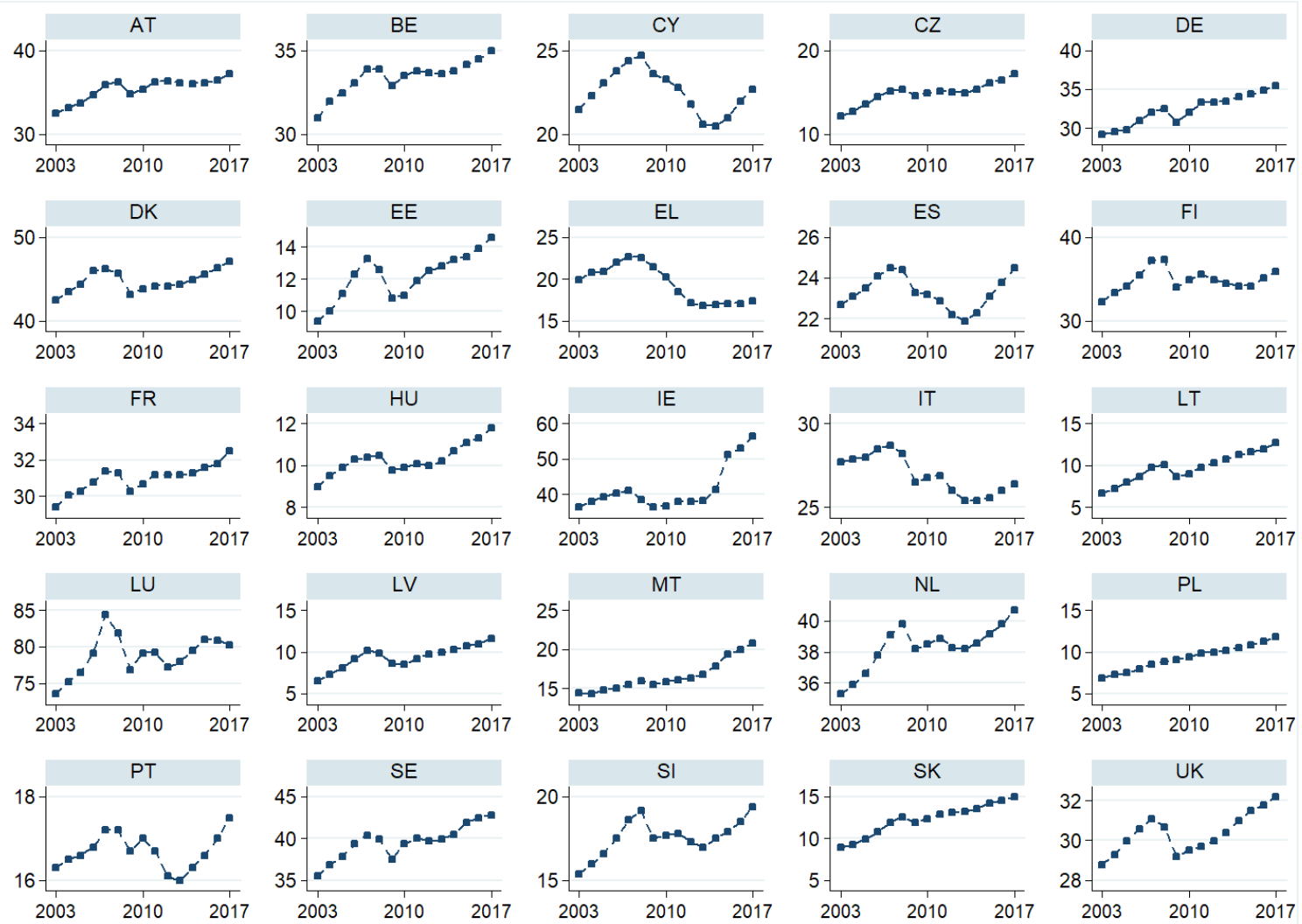

Source: Eurostat

Notes: Constant 2010 prices, EUR in thousands. 2003-2017. AT - Austria, BE - Belgium, CY - Cyprus, CZ - Czechia, DE - Germany, DK - Denmark, EE - Estonia, EL - Greece, ES - Spain, FI - Finland, FR - France, HU - Hungary, IE - Ireland, IT - Italy, LT - Lithuania, LU - Luxembourg, LV - Latvia, MT - Malta, NL - the Netherlands, PL - Poland, PT Portugal, SE - Sweden, SI - Slovenia, SK - Slovakia, UK - the United Kingdom. 
Figure 2 Unemployment rates in the European Union
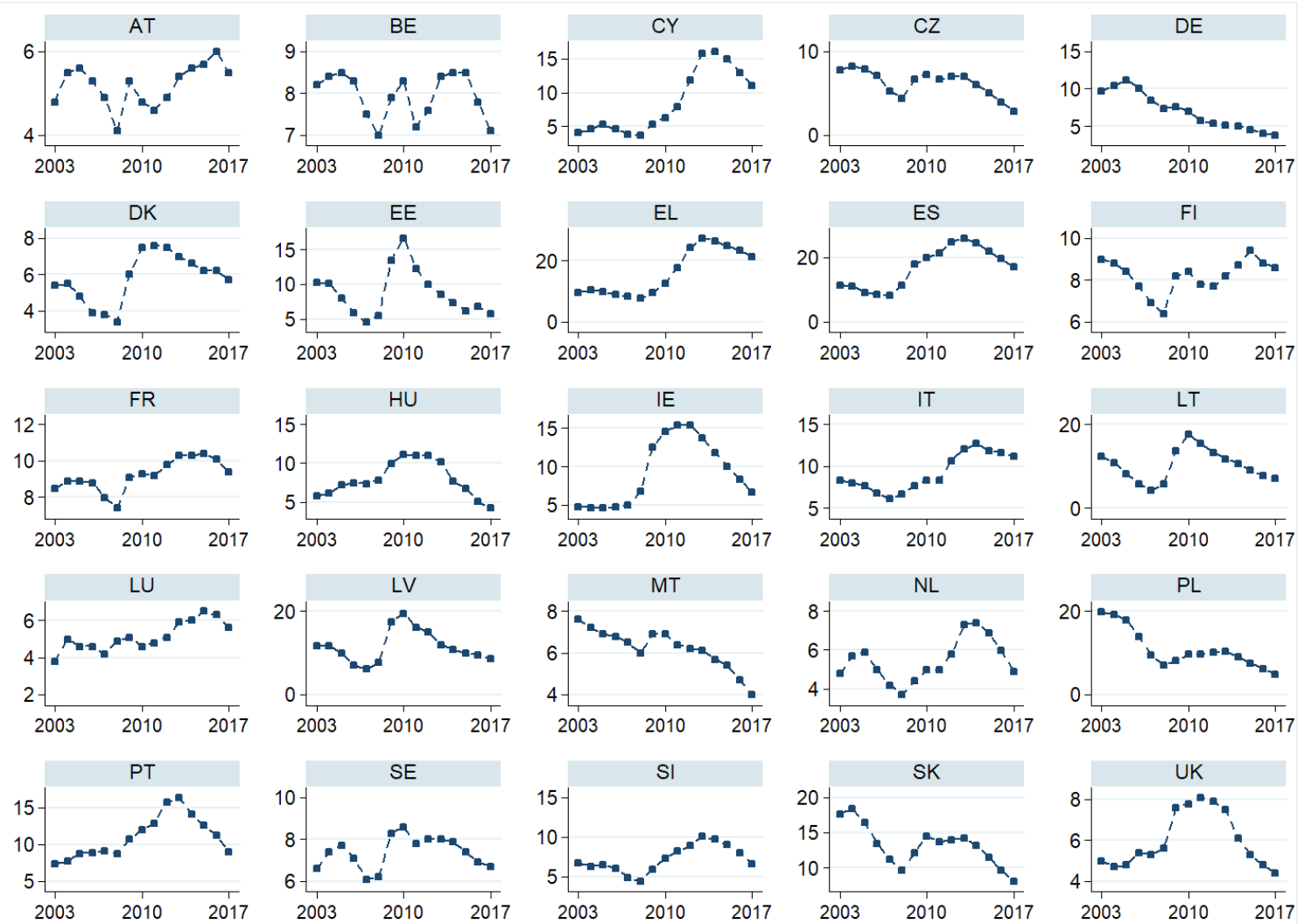

Source: Eurostat

Notes: 2003-2017. AT - Austria, BE - Belgium, CY - Cyprus, CZ - Czechia, DE - Germany, DK - Denmark, EE - Estonia, EL - Greece, ES - Spain, FI - Finland, FR - France, HU Hungary, IE - Ireland, IT - Italy, LT - Lithuania, LU - Luxembourg, LV - Latvia, MT Malta, NL - the Netherlands, PL - Poland, PT - Portugal, SE - Sweden, SI - Slovenia, SK Slovakia, UK - the United Kingdom. 


\section{Migration and inequality - what do we know?}

In its manifold forms and contexts, economic inequality has been a key public policy issue and a central topic in the economic literature (see Milanovic (2011) for a thorough review). The literature points to a complex relationship between economic inequality and migration. Migration changes the composition of the sending and receiving countries' populations in terms of the distribution of social and demographic characteristics, such as skills, gender, and age. Kahanec and Zimmermann $(2011,2014)$ provide an overview of migration's impacts on economic inequality, modelling the anatomy of the relationship using the Gini coefficient as the measure of inequality. Migrants move with their human capital, sometimes with their welfare benefit entitlements, and usually with a part of their wealth. They make many decisions affecting their social and labour market integration in the receiving countries. Migrants also affect the choices made by other actors, including the natives in the receiving countries (e.g., whether to invest in additional human capital), stayers in the sending countries (e.g., how much labour to supply given the remittances from family members abroad), and firms (e.g., how much, in which location, and in what technology to invest). More broadly, the effects of migration depend on the extent to which immigrants are integrated into the host society's labour market (Kahanec and Zimmermann, 2011). All of this may have consequences for how migration affects both within- and between-country economic inequalities.

\subsection{Migration and cross-country inequality}

The neoclassical economic theory predicts that income differentials trigger migration and that, in the long-run, migration contributes to reducing inequality. Specifically, the theory posits that imbalances in the supply of and demand for labour between countries result in earnings differentials, which drive migration flows from low-wage countries to those with higher wages (Harris and Todaro, 1970). Migration of labour has the potential to improve the efficiency of the allocation of production factors and thus to benefit both the sending and receiving economies (de Haas, 2010; Kahanec and Zimmermann, 2016; Kahanec and Guzi, 2017). The receiving countries gain an additional labour force available to domestic employers, while the sending countries benefit from remittances and skills acquired by return migrants. As migration alleviates the initial imbalances and wages converge, the baseline model predicts lower levels of income inequality between countries in the long run.

Going beyond the baseline model, the effects of immigration on wages and employment in the receiving countries have been studied using three main approaches: the spatial correlations approach, comparing the impact on natives in regions with high and low 
immigration; the skill-based approach, comparing the impacts of immigration on natives across skill (or occupation) groups using a production function; and a mixed approach that exploits immigration both across skill groups and across regions (Dustmann et al., 2016). Under all these approaches, the extent to which migration affects inequality positively or negatively largely depends on the skills of immigrants and, in particular, on whether immigrants and natives are substitutes or complements (Borjas, 2003; Card, 1990; Constant and Massey, 2005; Ottaviano and Peri, 2012; Peri and Sparber, 2009; Peri, 2007; Roy, 1997). ${ }^{5}$ These studies, reviewed by Constant (2014) and Peri (2014), mostly find no adverse employment or earnings effects of immigrant inflows on natives at the aggregate level, although some of them find a degree of substitutability and competition among low-skilled workers (typically uneducated, young and inexperienced, or recent immigrants).

Several studies identify positive income, productivity, and employment effects of immigration in the receiving countries (Constant, 2014; Peri, 2014). A World Bank report (2005) estimates that migration from developing countries increases the labour force of highincome countries by 3 percent, and the income of natives in high-income countries by 0.4 percent. This result is supported by Ortega and Peri (2009), who estimate that a 1 percent increase in immigration raises the total GDP in OECD countries by about 1 percent, without affecting average wages or labour productivity. Felbermayr et al. (2010) use international bilateral migration data for 2000 to provide evidence that an increase in the immigrant population leads to an income gain (per capita) in the receiving economy. D'Amuri and Peri (2014) document a positive effect of immigration on the employment and occupational attainment of natives, especially in countries with more flexible labour market regulation. Cattaneo et al. (2015) find a similar effect on native self-employment. Ottaviano, Peri, and Wright (2013) find evidence that immigration reduces offshoring of jobs. Kahanec and Guzi (2017) and Guzi et al. (2018) show that immigrants in the EU respond to skill shortages more flexibly than do the natives, putting their skills to use where they are most needed and greasing the receiving countries' labour markets. Kahanec and Pytliková (2017) show positive effects on the employment rate and GDP per capita in the old EU states of immigration from the new EU member states, and mixed effects for immigration from Eastern Partnership countries. These studies suggest that immigration may strengthen the economies of receiving countries, and thus cast doubts on the baseline model's implication that migration reduces betweencountry inequality.

\footnotetext{
${ }^{5}$ See Figure 3 for the skill composition of migration in Europe.
} 
However, there is also evidence of positive effects of out-migration on the per capita income of sending countries. This may occur by means of increased wage growth, the improved employment of stayers, or the positive impact of remittances on economic development. The EU enlargements in 2004 and 2007 led to higher labour mobility within the EU and contributed to increasing wages and decreasing unemployment in the new member states (Kahanec, 2013; Zaiceva, 2014). Two studies using household survey data by Dustmann, Frattini and Rosso (2015) and Elsner (2013) show that emigration had a positive effect on the wages of stayers in Poland and Lithuania, respectively. Dustmann et al. (2015) find the largest wage gain for workers with intermediate skills - the group that experienced the largest reduction through emigration in Poland.

The sending countries may benefit from emigration through remittances, technological transfers (Fassio et al., 2019), or trade and capital flows (Kugler and Rapoport, 2005). Remittances, in particular, have been shown to contribute to economic growth (Catrinescu et al., 2009; Glytsos, 2002), thus potentially reducing inequality between countries. Catrinescu et al. (2009) find a positive effect of remittances on economic growth in a dynamic panel data analysis of 162 countries followed over a 34-year period. An important finding is that the extent to which remittances impact economic development depends on the quality of political and economic policies and institutions. Fayissa and Nsiah (2010) show that remittances provide an alternative way to finance investment and help to overcome liquidity constraints in African countries and thus contribute to economic growth. Some studies find a negative correlation between remittances and economic growth. Chami, Fullenkamp, and Jahjah (2005) use data on 113 developing countries over the 1970-1998 period to show the existence of a public moral hazard: the income from remittances reduces the incentives of the receiving household to take up employment, thus reducing overall productivity.

The sending countries are, however, also affected by the loss of population and human capital, referred to as a 'brain drain'. The outflow of skilled workers may leave a developing country in a poverty trap while increasing the productivity of the developed world (Ozden and Schiff, 2006). On the other hand, Mountford (1997) presents a theoretical model of a small open economy with endogenous education decisions to show that the possibility of emigration increases the human capital accumulation which, in the long-run, outweighs the losses incurred by a brain drain. In the same vein, Stark (2004) argues that the behavioural response to the prospect of migration can lead to both a brain drain and a brain gain: as migration rewards those with an education, more individuals are incentivised to get an education, which may stimulate economic development. There are additional effects that may mitigate the negative direct 
impacts of a brain drain for the sending countries, including higher remittances; positive externalities from the diaspora; return or circular migration channelling experienced, up-skilled professionals back home; and the creation of trans-border investment, business, trade, and knowledge networks fostering economic activity and the transfer of capital, technology, and innovation between sending and receiving countries. Docquier (2006) reviews a large strand of literature focusing on the gains and losses of a brain drain and concludes that the optimal emigration rate of skilled workers that maximises (both sending and receiving) country gains is between 5 and 10 percent, whereas emigration of more than 15 percent of the source population becomes harmful for the country's development. Kahanec (2013) argues that increased migration within the EU after the 2004 and 2007 enlargements contributed to some gainful 'brain circulation' for the sending countries, although relatively large out-migration from some of the new member states poses serious risks for their long-run prosperity and public budgets.

Several studies looked at the overall impacts of migration on economic inequality across countries. While international migration is seen as a positive-sum game because it generates income gains at the international level, Sanderson (2013) argues that the gains are highest for wealthier countries. High-income countries boast highly-developed technological infrastructures, advanced forms of production, and an educated labour force that enable them to benefit from immigration (Sanderson, 2013). Moreover, in a global labour market, certain countries act as magnets for the highly skilled, which further reinforces their human capital, possibly to the detriment of others (Perrons, 2009). Although the sending countries may benefit as well, their benefits from migration depend on a number of factors such as the nature of migration (temporary, permanent, circular, transnational), the total flow of remittances and their spending, the magnitude and selection of return migration, and the engagement between the diaspora and home region through capital or skill transfers (Perrons, 2009). Kapur and McHale (2009) use a sample of 134 countries to estimate that international migration raises global income per capita by 1 percent and reduces between-country inequality by 2 percent. Based on this evidence, whether migration exacerbates or alleviates income inequalities between countries remains an open question.

\subsection{Migration and within-country inequality}

The effects of migration on within-country inequality differ for receiving and sending countries. Empirical studies suggest a U-shaped relationship between migration and inequality in sending countries: migration increases inequality in the short-term and has an equalising effect once 
migration networks grow (Mckenzie and Rapoport, 2007). This is because the initial migration is costly and migration networks are not well developed. Thus, migrants tend to be overrepresented from the upper or middle ranges of the wealth distribution of households. In this case, migration increases inequality as households in the upper and middle part of income distribution benefit from the remitted income earned abroad.

Migration networks expand over time, which helps to decrease the cost of migration and improves access to economic resources, thus enabling also poorer individuals to migrate. The benefits of migration are then spread to a broader range of members of society, and the overall impact of migration may reduce inequality. Depending on which part of the income and wealth distributions the migrants originate from, their departure by itself may increase or decrease economic inequality.

There is overwhelming evidence that the country of origin of immigrants matters for their labour and social outcomes in the receiving countries (e.g., Zimmermann, 2005; Chiswick, 1978; Borjas, 1985, 1987). Interestingly, Borjas (1987) finds that immigrants from countries with higher income inequality exhibit less favourable labour market outcomes in the US. Stark (2006) argues that an important feedback loop works through the selectivity of migrants with different skill levels as a function of inequality in the receiving countries. The basic framework that explains self-selection into immigration is the Roy model (see Borjas (1987) for a formalisation of the model based on Roy (1951)). The model predicts that high-skilled immigrants are attracted to more unequal countries and low-skilled immigrants are attracted to less unequal countries. Dustmann et al. (2011) present a dynamic Roy model, in which skills vary over time, and they show a potential brain gain associated with return migration.

The overall effects of migration on inequality also depend on the effects of immigration on wages. In line with conventional economic thinking, Davies and Wooton (1992) suggest that unskilled immigration is likely to increase income inequality by lowering wages in the lowskill segment of the labour market, while skilled immigration is likely to reduce income inequality by lowering the high-skill wage premium. Kahanec and Zimmermann (2010, 2016) distinguish the effects taking place through the changing skill composition of the labour force and the effects operating through wage adjustment. They argue that the effect of immigration on inequality depends on the skills of the immigrants and the substitutability of labour between immigrants and natives, but also on the distribution of skills in the receiving countries.

To illustrate the changing structure of migration in Europe we calculate the share of skilled immigrants residing in the EU using the Institute for Employment Research (IAB) braindrain dataset (Brücker et al., 2013). These data are available for 14 EU countries in five-year 
intervals until 2010 and includes the number of immigrants residing in each country by educational level. Figure 3 documents the increasing share of immigrants with upper secondary and tertiary education during 1995-2010 in the selected EU countries. Notably, most countries have registered a steep increase in the share of skilled immigrants during the period. One exception is Denmark, where the increasing trend reverted in 2010. Importantly, in 12 of the 14 countries, highly qualified migrants (with upper secondary or tertiary education) comprised the majority of the immigrant population in 2010 .

Figure 4 reports the varying levels of the Gini coefficient calculated using disposable income. Between 2003 and 2017, inequality has decreased in many countries including Belgium, Czechia, Estonia, Finland, Latvia, Poland, Portugal, Slovakia, and the United Kingdom although inequality increased steeply in Cyprus, Germany, Denmark, France, Luxemburg, Malta, Spain, and Sweden and remained rather flat in Austria, Greece, Hungary, Ireland, Italy, Lithuania, the Netherlands, and Slovenia.

In much of Europe the Gini is below 30 indicating the relatively low income inequality that is generally attributed to governments' redistribution policies. Avram, Levy, and Sutherland (2014) calculate that the redistributive effect of taxes and benefits in the whole EU27 is, on average, around 20 Gini points. The extent of redistribution varies from 11 points in Cyprus to 26.5 points in Belgium and authors find that the public pensions and income tax schedules are the strongest determinants of redistributive effect.

Comparing migration and inequality in different US cities between 1980 and 2000, Card (2009) proposes that immigration had only a small impact on wage inequality among natives. However, as immigrants are concentrated in the upper and lower tails of skill distribution, Card argues that a larger share of immigrants contributes to higher overall income inequality in the United States. On the other hand, Kahanec and Zimmermann (2014) argue that immigration reduced inequality in the OECD countries. They explain that this effect is caused by the increasing share of skilled workers in the economy (through immigration or the upskilling of natives) that narrows the wage differential between high- and low-skilled workers.

The effect of immigration on inequality is further inflated or deflated by the response of the resident population to the migration influx. In response to immigration, native workers may invest in their human capital (Chiswick, 1989), may change their occupations or the content of their tasks (Giuntella et al, 2019; Sebastian and Ulceluse, 2019; Amuedo-Dorantes and de la Rica, 2011), or may themselves migrate to another city, region or country (Card, 2001). The relationship between immigration and inequality can be further affected by national-level policies, which themselves may respond to immigration (Guzi et al., 2015). Immigrants 
contribute to public budgets, which then may be used for redistributive measures and potentially reduce inequality (Andersen et al., 2019). Furthermore, governments may make welfare more (or less) accessible in countries with more immigration (Giulietti et al., 2013). The mobility of workers within the EU after the recent enlargements also came with socioeconomic cleavages between workers from the new EU member states and the incumbent labour force in the receiving countries (Guzi and Kahanec 2015; Meardi 2012).

The available empirical evidence on the distributional impact of remittances confirms the theoretical predictions that the effect of immigration on inequality in sending countries depends on the structure of migration. Adams (1989) and Milanovic (1987) find a positive effect of remittances on income inequality in the sending country because many migrants came from high-income households, which then benefited from remittances more than low-income households. Conversely, following migration patterns and remittances in Yugoslavia from 1973 to 1983, Milanovic (1987) finds that overall inequality went down in years when a higher remittance income was received by a less-skilled (agricultural) household . 
Figure 3 The share of immigrants by educational level
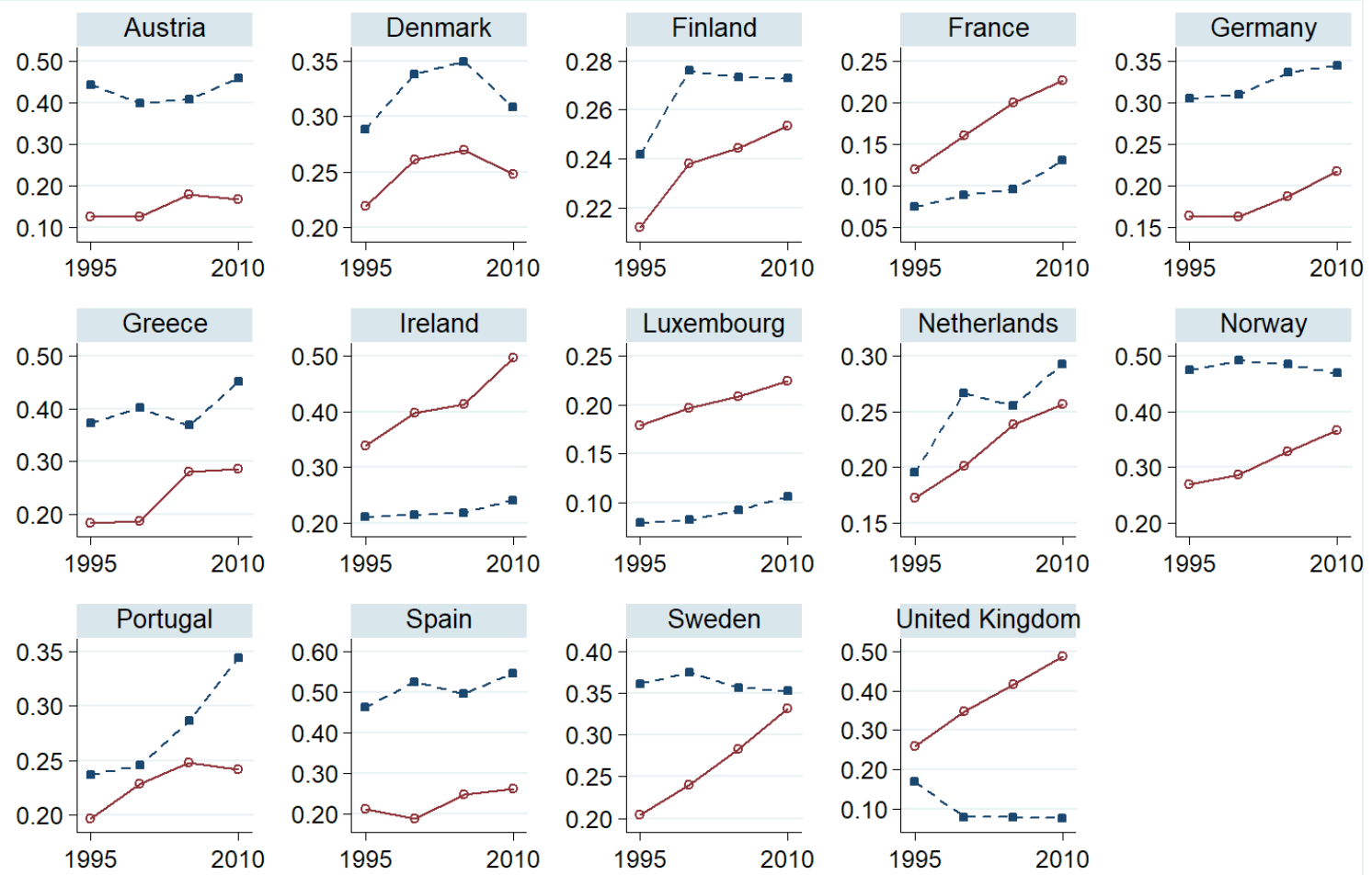

Upper secondary

Tertiary

Source: Authors' calculation based on Brücker, Capuano, and Marfouk (2013).

Note: 1995-2010. The underlying data refers to the total number of foreign-born individuals aged 25 years and older living in a country, distinguished by educational level. The category representing the share of immigrants with lower secondary, primary and no schooling is omitted from the graph. Data is only available for 14 EU countries in five-year intervals until 2010 . 
Figure 4 Inequality in the EU
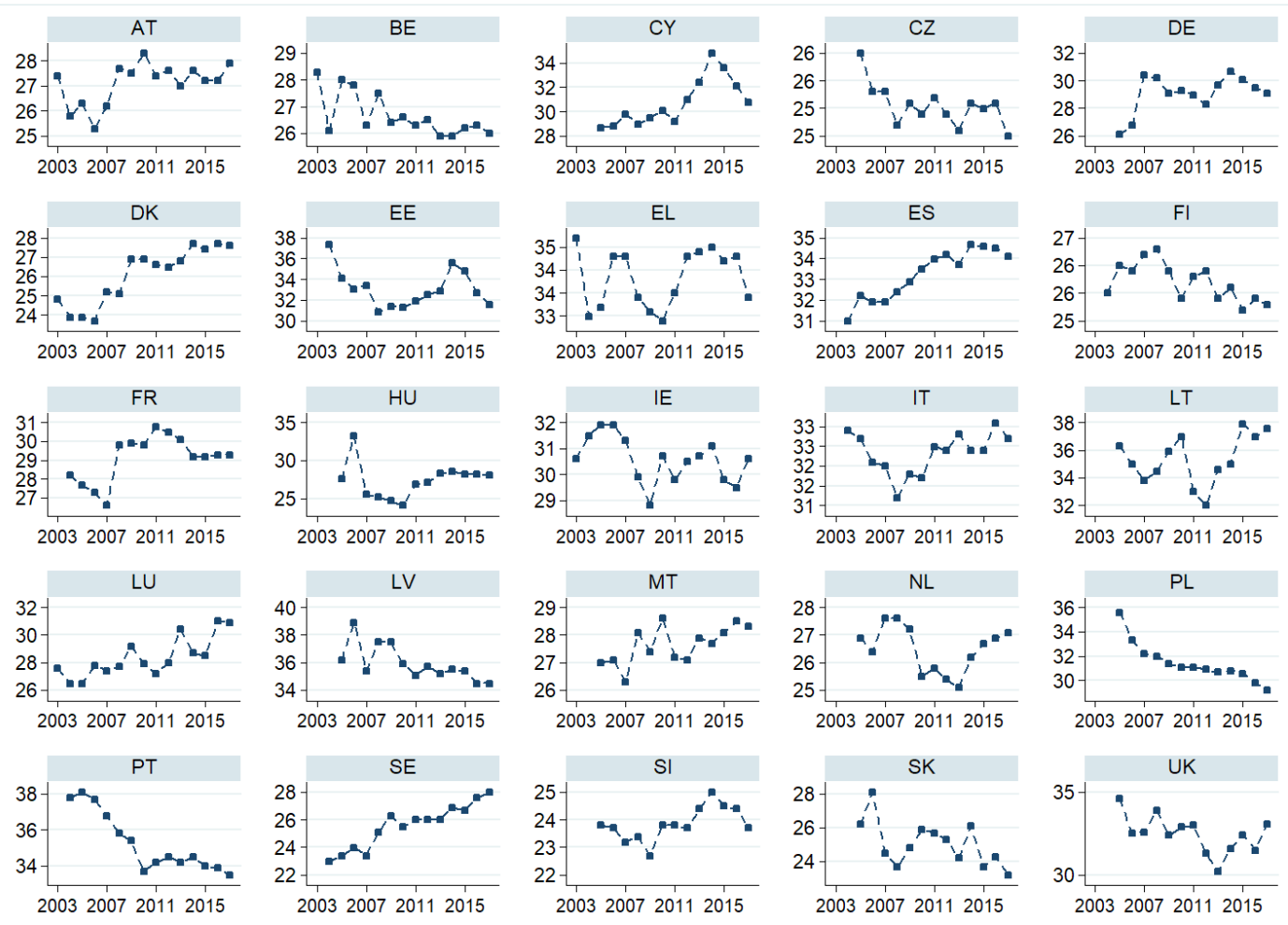

Source: Authors' calculation based on Eurostat (2019a).

Note: 2003-2017. The Gini coefficient is calculated based on equalised disposable income. 


\section{Immigration and economic inequality in European Union member states}

\subsection{Data and descriptive statistics}

To empirically assess the effects of migration on inequality in the EU, we construct an unbalanced panel of 25 countries over the 2003-2017 period. ${ }^{6}$ The estimation sample includes 311 country-year observations. Our measure of income inequality is the Gini index based on equalised disposable income (Eurostat, 2019a). This measure is calculated based on household income from the European Union Statistics on Income and Living Conditions (EU-SILC) that is harmonised and standardised both over time and between countries. To analyse the connection between migration and inequality, we use the migration inflow and stock variables from Eurostat (Eurostat, 2019b). The definition of a migrant is based on foreign citizenship. Unfortunately, statistics on migration are not available for all years and all EU countries, and the data does not permit us to distinguish migration statistics by different origins. To control for a range of possible confounding factors, we further compile data on the GDP per capita, unemployment rate, trade openness (measured as exports plus imports as a share of GDP), inflation, the share of population with tertiary education, and industry structure (employment in the agricultural sector). Table A1 in the Appendix provides the definitions and sources of all the variables.

The basic descriptive statistics of the main variables used in the analysis are reported in Table 1 separately for periods before and after the beginning of the Great Recession. Additionally, we split countries by the size of immigrant stock into high (above-median) and low (below-median) group. The migration variables are expressed per 1,000 population and exhibit large variation in the studied sample. The average annual migration inflow is $0.8 \%$ (7.5 per 1,000$)$ and the average share of immigrants in the total population is $6.6 \%$. The countries with high immigrant stocks exhibit larger immigrant inflows, but the rate of growth of the immigrant stocks is relatively faster in low immigrant countries. Countries with higher immigrant stocks have on average a higher GDP per capita and unemployment, lower government expenditures, more educated workforce, higher trade-openness, and lower employment in agriculture. Many of the differences between high and low immigrant countries have become narrower in the period after the beginning of the Great Recession. Interestingly income inequality remains very similar in these two groups of countries over time.

\footnotetext{
${ }^{6}$ The sample includes Austria (AT), Belgium (BE), Cyprus (CY), Czech Republic (CZ), Denmark (DK), Estonia (EE), Finland (FI), France (FR), Germany (DE), Greece (EL), Hungary (HU), Ireland (IE), Italy (IT), Latvia (LV), Lithuania (LT), Luxemburg (LU), Malta (MT), Netherlands (NL), Poland (PL), Portugal (PT), Slovakia (SK), Slovenia (SI), Spain (ES), Sweden (SE), and the United Kingdom (GB). We could not include Bulgaria, Croatia, and Romania in the sample due to missing migration data in the Eurostat database.
} 
Table 1 Summary statistics for the main variables

\begin{tabular}{lrrrr}
\hline Period & \multicolumn{2}{c}{$2003-2009$} & \multicolumn{2}{c}{$2010-2017$} \\
Immigrant stock & \multicolumn{1}{c}{ high } & \multicolumn{1}{c}{ low } & \multicolumn{1}{c}{ high } & \multicolumn{1}{c}{ low } \\
\hline Gini & 29.84 & 30.48 & 30.88 & 30.27 \\
Inflow per 1,000 & 10.6 & 5.7 & 9.7 & 6.5 \\
Stock per 1,000 & 91.3 & 40.7 & 100.3 & 55.9 \\
Government expenditure & 44.4 & 46.9 & 45.8 & 48.6 \\
GDP per capita & 10.23 & 10.04 & 10.27 & 10.10 \\
Unemployment rate & 9.4 & 8.0 & 11.5 & 8.8 \\
Trade openness & 75.4 & 70.0 & 87.9 & 80.8 \\
Tertiary education & 25.8 & 22.6 & 30.6 & 29.2 \\
Employment in agriculture & 3.8 & 4.9 & 3.2 & 3.8 \\
Inflation & 2.2 & 2.3 & 1.3 & 1.5 \\
\hline
\end{tabular}

Source: Eurostat

Note: Countries are split by the size of immigrant stock into high (above-median) and low (below-media) group. Figures are weighted by population size.

\subsection{The empirical framework}

The empirical framework is based on a standard dynamic linear panel model that exploits variation within countries over time:

gini $_{c t}=\beta_{1}$ inflow $_{c t-1}+\beta_{2}$ stock $_{c t-1}+X_{c t-1} \gamma+\eta_{t}+\eta_{c}+\varepsilon_{c t}$

where gini $_{c t}$ measures net income inequality for country $c$ in period $t$; inflow ct-1 $_{c t}$ and stock $_{c t-1}$ are lagged measures of the annual immigrant inflow and the size of migrant population relative to population size in a country; $X_{c t-1} \gamma$ is a vector of lagged control variables and their corresponding coefficients; $\eta_{t}$ and $\eta_{c}$ denote a time effect and a time-invariant country-specific fixed effect; and $\varepsilon_{c t}$ is an idiosyncratic error term. Including country-fixed effects helps to remove the effect of time-invariant institutional differences that may affect income inequality but do not vary over time during the studied period. All of the explanatory variables are lagged by one year to partly alleviate the possible problem of simultaneity. A simultaneity bias could affect our results if a reverse channel of causation was present and inequality was affecting, rather than being driven, by those explanatory variables. Observations are weighted by countries' population size, and standard errors are corrected by applying the Huber and White robust variance estimator.

A particular problem of simultaneity arises with respect to the key explanatory variable, migration flows and stocks. Based on the literature reviewed earlier, it is possible that 
immigration flows and stocks are endogenous, responding to inequality in receiving countries. We address this endogeneity problem with the instrumental variable, or two-stage least squares, (2SLS) approach. A suitable instrumental variable is required to be independent of $\varepsilon_{c t}$ in Equation 1, but correlated with the migration variables. We construct instrumental variables based on historical immigration. There is a consensus in the literature that migrant networks facilitate immigration, as immigrants are attracted to settle where there are existing networks with the same cultural or linguistic background as themselves (Borjas, 1994; Card, 2001). Therefore, past immigrant inflows are a good predictor of contemporary inflows. We assume that past inflows are not directly correlated with current income inequalities if measured with a sufficient time lag. We use past migration variables with a four-year lag as instruments. ${ }^{7}$ The identification thus rests on the assumption that current inequalities are not affecting past immigration through expectations or serial correlation of the migration variables.

Columns 1 and 2 in Table 2 report the ordinary least squares (OLS) estimates from fixed and random effects models. The random effects model emphasises the importance of modelling heterogeneity using random coefficients and is more efficient than the fixed effects model. ${ }^{8}$ Column 3 presents the results from the second stage of the 2 SLS regression. ${ }^{9}$ The key result of this analysis is that the estimated coefficients consistently show across all three models that migration inflows and immigrants stocks decrease income inequality in the receiving countries. In the 2SLS model, the effect of immigrant stocks remains negative, but loses significance. The calculated elasticities based on 2SLS estimates are 0.035 and 0.031 for inflow and stock variables, respectively. This implies, approximately, that a $10 \%$ increase in migration inflow decreases the Gini index by $0.3 \%$. As for the other variables, the results are generally consistent with the literature. We find that government spending, openness to trade, and the share of the educated labour force decrease economic inequality, while unemployment and employment in agriculture increase economic inequality. These results are consistent with the previous literature (see e.g., Kahanec and Zimmermann, 2014; Guzi and Kahanec, 2019).

We note several limitations to our analysis. First, we employ data on immigration flows from the Eurostat that provides data for only a limited number of countries and for a relatively

\footnotetext{
${ }^{7}$ The results are practically identical when the inflows lagged by three years are used.

${ }^{8}$ We run a Hausman test, which confirms that the results of both models are consistent (i.e. the test cannot reject the random effects model).

9 The first-stage regressions (presented in Table A2 in Appendix) are estimated for each migration variable separately and with the same controls as well as country and year fixed effects as the second stage. The estimated coefficient on the lagged migration variables from the first-stage are significant. The first-stage Cragg-Wald $\mathrm{F}$ statistics are equal to 27 and 87, which surpass the value 10 for the test of weak instrument (Stock et al., 2002). We can also reject at the $1 \%$ level the null hypotheses of under-identification and weak instruments as proposed by Sanderson and Windmeijer (2016).
} 
short period, possibly insufficient to detect long-run effects of immigration on inequality. Additionally, the available data does not allow us to distinguish between different types of flows (e.g., high- vs. low-skilled), or between different countries of origin. Third, our results reflect an aggregate effect across countries and over time. It is possible that the magnitude (and perhaps the direction) of the effect would be different for different (groups of) countries. Nevertheless, this analysis provides an insight into the relationship between immigration and within-country inequality in the context of the EU, a significant immigrant destination. ${ }^{10}$ Future research aimed at distinguishing between, for example, the effects of high- and low-skilled immigration, immigration from different origins, or immigration under different institutional and policy regimes would be needed to shed more light on this complex relationship.

\footnotetext{
${ }^{10}$ As a robustness check, we split the sample into two sub-periods. We confirm that estimates from 2SLS regression remain significant in the period after the crisis (2010-2017) while estimates in the pre-crisis period are not significant. Furthermore we find that the estimates are significant in countries hit less by the financial crisis (when measured by the increase in unemployment after 2009). In our estimations, observations are weighted by countries' population size, so that results are not driven by small countries (e.g., omitting Luxembourg from estimation sample has no impact on our results).
} 
Table 2 Determinants of income inequality

\begin{tabular}{|c|c|c|c|}
\hline & $\begin{array}{l}\mathrm{RE} \\
\text { (1) }\end{array}$ & $\begin{array}{l}\text { FE } \\
\text { (2) }\end{array}$ & $\begin{array}{l}\text { 2SLS } \\
\text { (3) }\end{array}$ \\
\hline Inflow per 1,000 & $\begin{array}{c}-0.063 * * \\
(0.025)\end{array}$ & $\begin{array}{c}-0.072 * * \\
(0.032)\end{array}$ & $\begin{array}{c}-0.123^{* *} \\
(0.056)\end{array}$ \\
\hline Stock per 1,000 & $\begin{array}{c}-0.013 * \\
(0.007)\end{array}$ & $\begin{array}{c}-0.023^{* *} \\
(0.010)\end{array}$ & $\begin{array}{l}-0.016 \\
(0.012)\end{array}$ \\
\hline Government expenditure & $\begin{array}{c}-0.175 * * * \\
(0.035)\end{array}$ & $\begin{array}{l}-0.138 * \\
(0.067)\end{array}$ & $\begin{array}{c}-0.148 * * * \\
(0.048)\end{array}$ \\
\hline GDP per capita & $\begin{array}{c}-38.933 * * \\
(18.486)\end{array}$ & $\begin{array}{c}-27.63 \\
(22.626)\end{array}$ & $\begin{array}{l}-27.319 \\
(28.766)\end{array}$ \\
\hline GDP per capita square & $\begin{array}{c}2.168 * * \\
(0.916)\end{array}$ & $\begin{array}{c}1.67 \\
(1.149)\end{array}$ & $\begin{array}{c}1.671 \\
(1.451)\end{array}$ \\
\hline Unemployment rate & $\begin{array}{c}0.146^{* * * *} \\
(0.029)\end{array}$ & $\begin{array}{c}0.142^{* * * *} \\
(0.047)\end{array}$ & $\begin{array}{c}0.121 * * \\
(0.050)\end{array}$ \\
\hline Trade openness & $\begin{array}{c}-5.123 * * * \\
(1.021)\end{array}$ & $\begin{array}{c}-5.556^{* *} \\
(2.193)\end{array}$ & $\begin{array}{c}-5.083^{* *} \\
(2.313)\end{array}$ \\
\hline Tertiary education & $\begin{array}{c}-0.205 * * * \\
(0.038)\end{array}$ & $\begin{array}{c}-0.273 * * * \\
(0.073)\end{array}$ & $\begin{array}{c}-0.281 * * * \\
(0.059)\end{array}$ \\
\hline Employment in agriculture & $\begin{array}{c}0.396^{* * * *} \\
(0.144)\end{array}$ & $\begin{array}{c}0.525 * * \\
(0.205)\end{array}$ & $\begin{array}{c}0.523 * * \\
(0.214)\end{array}$ \\
\hline Inflation & $\begin{array}{c}0.088 \\
(0.074)\end{array}$ & $\begin{array}{c}0.092 \\
(0.124)\end{array}$ & $\begin{array}{c}0.11 \\
(0.079)\end{array}$ \\
\hline Constant & $\begin{array}{l}233.6 * * \\
(94.258)\end{array}$ & $\begin{array}{c}176.8 \\
(114.143)\end{array}$ & $\begin{array}{c}169 \\
(144.690)\end{array}$ \\
\hline Sample size & 311 & 311 & 311 \\
\hline R2/Within R2 & 0.42 & 0.43 & \\
\hline First stage F-stat (inflow) & & & 27.4 \\
\hline First stage F-stat (stock) & & & 87.3 \\
\hline
\end{tabular}

Source: Own calculations based on data from Eurostat.

Notes: Estimates from fixed effects (FE), random effects (RE) and two-stage least squares (2SLS) regression analysis. Dependent variable is the Gini index based on equivalised disposable income. Explanatory variables are lagged 1 year and all models include year fixed effects. Observations weighted by population size. $*<0.10$, $* *<0.05, * * *<0.01$. 


\section{Discussion and Conclusions}

Human migration affects the size and composition of populations in the sending and receiving countries. In consequence, it has an impact on the supply and demand and the nature of competition in their labour markets. Additional effects arise in the markets for goods, services, capital, and technologies. Migration may have further economic impacts through its effects on preferences, social norms, or behaviours and on choices of receiving and sending populations and migrants themselves.

This chapter reviews what we know about the effect of migration on income inequality within and across countries of the European Union. The review of the existing literature suggests that the baseline economic model of migration, which predicts that the international mobility of workers should decrease international wage differentials, does not capture important effects that may in fact work against this prediction. This is not least because labour is heterogeneous, and immigrant workers bring along skills to countries, sectors, and occupations where they are most needed and where they complement the skills possessed by the natives. The receiving countries may also benefit from brain gain and the creation of new trade, investment, and knowledge networks facilitated by immigrants. Hence, immigration provides new economic resources and helps to fill in the bottlenecks and grease the wheels of economic growth and wealth creation in the receiving countries. On the other hand, while the sending countries may lose due to brain drain, they also may benefit from remittances, brain circulation, or the positive effects of out-migration on wages and employment opportunities. The overall net effect of migration on economic inequalities across countries thus remains an open empirical question.

Looking at the effects of migration on within-country economic inequality, the literature establishes that they largely depend on the skill-mix of migrants or, more precisely, on migration's impacts on the composition of the labour force in the respective labour market. While high-skilled immigration presents the potential to reduce inequality by lowering the gap between the wages of low- and high-skilled workers in the receiving countries, low-skilled immigration can increase inequality by expanding the supply of low-skilled workers in receiving countries and decreasing their wages or increasing their unemployment. The corresponding opposite effects can be expected for out-migration. Additional effects on the skill composition of workers may arise through the reaction of the incumbent labour force in the receiving labour markets or the stayers in the sending countries, as well as through the effects of remittances and public budgets and redistribution. Several channels of interaction between migration and inequality may be at play simultaneously, and their salience is likely to vary 
across migration sources, types, and selectivity; economic, demographic, and institutional and policy contexts; and the responses of the receiving society and migrants themselves. The overall net effect of migration on within-country inequality is the composite of these effects and is context-dependent. At the very general level, labour mobility empowers workers and provides them with additional alternatives, which can be expected to increase labour's share in income and, because capital income is more concentrated than labour income, decrease income inequality.

Our own empirical results show that immigration has contributed to reducing inequality within the 25 EU countries over the period analysed. Importantly, as we show that EU member states have attracted relatively highly qualified immigrants throughout this period, our results are consistent with the ameliorating effect of skilled immigration on within-country inequality, as predicted by theory. This finding has important policy implications for receiving countries, that experience an acute need for skilled labour and are increasingly aware of the detrimental effects of inequality for their societies. Specifically, our findings suggest that immigration may be a mechanism that reduces income inequality. By attracting qualified immigrants, receiving societies may satisfy two needs with one deed: respond to the existing demand for skilled labour and reduce economic inequality.

To conclude, migration and inequality interact through a variety of channels, some of which work through the composition of the sending and receiving populations, others through the effects on the nature of competition in the sending and receiving labour markets, and yet others through the effects of migration on business, trade, investment and innovation patterns. Institutions and policies may affect or intermediate the relationship between migration and inequality. In fact, they may respond to migration; Giulietti et al. (2013) provide some evidence that redistribution policies become more generous in countries that have experienced more immigration. The literature and our own results suggest that immigration may decrease inequality in the receiving EU countries. However, the relationship between migration and economic inequality requires further research to map its complex interactions with various institutional and policy contexts, its dependence on different types of migration and its origins and destinations. That attitudes towards immigration did not deteriorate and, in fact, might have improved in spite of what is called the European migration crisis, gives hopes that the EU will be able to reach a compromise over its migration framework that will nurture the benefits from migration and immigration and at the same time win acceptance by its citizens.

The 2020 COVID-19 pandemics and its dire consequences will make reaching these objectives increasingly more complex, but they may also catalyse new innovative approaches 
to the governance of (global) public goods, including migration and labour mobility. Certainly, it will provide a rare opportunity to study the impacts of migration on economic inequality in a natural experiment setting.

\section{Acknowledgments}

The authors gratefully acknowledge the support from Slovak Research and Development Agency (grant APVV-15-0765: Inequality and economic growth). Martin Guzi acknowledges the support from the Czech Science Foundation (grant No. 20-31615S). Martin Kahanec very much appreciates the support by his Mercator Fellowship at Bruegel during the final stages of writing this chapter.

\section{References}

Acemoglu, D., Johnson, S., and Robinson, J. A. (2001). The colonial origins of comparative development: An empirical investigation. American Economic Review, 91(5), 1369-1401. https://doi.org/10.1257/aer.91.5.1369

Adams, R. H. (1989). Worker remittances and inequality in rural Egypt. Economic Development and Cultural Change, 38(1), 45-71. https://doi.org/10.1086/451775

Alabrese, E., Becker, S. O., Fetzer, T., and Novy, D. (2019). Who voted for Brexit? Individual and regional data combined. European Journal of Political Economy, 56, 132-150.

Amuedo-Dorantes, C., and de la Rica, S. (2011). Complements or substitutes? Task specialization by gender and nativity in Spain. Labour Economics, 18, 697-707.

Andersen, L. H., Dustmann, C., and Landers $\varnothing$, R. (2019). Lowering welfare benefits: Intended and unintended consequences for migrants and their families. The Rockwool Foundation Research Unit. Study Paper No. 138. Copenhagen: Rockwood Foundation.

Arnorsson, A., and Zoega, G. (2018). On the causes of Brexit. European Journal of Political Economy, 55, 301-323.

Avram, S., Levy, H., and Sutherland, H. (2014). Income redistribution in the European Union. IZA Journal of European Labor Studies, 3(1), 22.

Bade, K. (2003). Migration in European history. London: Blackwell Publishing.

Barou, J. (2006). Europe, Terre d'immigration: Flux Migratoires et Intégration. Grenoble: Presses Universitaires de Grénoble.

Becker, S. O., Fetzer, T., and Novy, D. (2017). Who voted for Brexit? A comprehensive district-level analysis. Economic Policy, 32(92), 601-650.

Borjas, G. J. (1985). Assimilation, changes in cohort quality, and the earnings of immigrants. Journal of Labor Economics, 3(4), 463-489. https://doi.org/10.1086/298065 
Borjas, G. (1987). Self-selection and the earnings of immigrants. American Economic Review, 77, 31-553.

Borjas, G. (1994). Economics of migration. Journal of Economic Literature, 32(4), 16671717.

Borjas, G. J. (2003). The labor demand curve is downward sloping: Reexamining the impact of immigration on the labor market. Quarterly Journal of Economics, 118(4), 1335-1374. https://doi.org/10.1162/003355303322552810

Brücker, H., Capuano, S., and Marfouk, A. (2013). Education, gender and international migration: insights from a panel-dataset 1980-2010. Methodology Report.

http://doku.iab.de/daten/brain-drain/iabbd_8010_v1_methodology.pdf

Card, D. (1990). The impact of the Mariel Boatlift on the Miami labor market. ILR Review, 43(2), 245-257. https://doi.org/10.1177/001979399004300205

Card, D. (2001). Immigrant inflows, native outflows and the local labor market impacts of higher immigration. Journal of Labor Economics, 90(2), 360-367.

Card, D. (2009). Immigration and inequality. American Economic Review, 99(2), 1-21. https://doi.org/10.1257/aer.99.2.1

Castles, S., and Miller, M. J. (1998). The age of migration (2nd ed.). Houndmills, UK: Macmillan.

Catrinescu, N., Leon-Ledesma, M. Matloob Piracha, M., and Quillin, B. (2009). Remittances, institutions, and economic growth. World Development, 37(1), 81-92.

https://doi.org/10.1016/j.worlddev.2008.02.004

Cattaneo, C., Fiorio, C. V., and Peri, G. (2015). What happens to the careers of European workers when immigrants 'take their jobs'? Journal of Human Resources, 50(3), 655-693. https://doi.org/10.3368/jhr.50.3.655

Chami, R., Fullenkamp, C., and Jahjah, S. (2005). Are Immigrant Remittance Flows a Source of Capital for Development? IMF Staff Papers, 52(1), 55-81.

Chetty, R., et al. (2016) The association between income and life expectancy in the United States, 2001-2014. Journal of the Americal Medical Association, 315(16), 1750-1766.

Chiswick, B. R. (1978). The effect of Americanization on the earnings of foreign-born men. Journal of Political Economy, 86(5), 897-921. https://doi.org/10.1086/260717

Chiswick, C. U. (1989). The impact of immigration on the human capital of natives. Journal of Labor Economics, 7(4), 464-486. https://doi.org/10.1086/298217

Constant, A. (2014). Do migrants take the jobs of native workers? IZA World of Labor. https://doi.org/10.15185/izawol.10

Constant, A., and Massey, D. S. (2005). Labor market segmentation and the earnings of German guestworkers. Population Research and Policy Review, 24(5), 489-512. https://doi.org/10.1007/s11113-005-4675-z 
D'Amuri, F., and Peri, G. (2014). Immigration, jobs, and employment protection: Evidence from Europe before and during the great recession: Immigration, jobs, and employment protection. Journal of the European Economic Association, 12(2), 432-464.

https://doi.org/10.1111/jeea.12040

Davies, J. B., and Wooton, I. (1992). Income inequality and international migration. Economic Journal, 102(413), 789. https://doi.org/10.2307/2234577

de Haas, H. (2010). Migration and development: A theoretical perspective. International Migration Review, 44(1), 227-264.

Docquier, F. (2006). Brain drain and inequality across nations. IZA Discussion Paper No. (2440). Bonn: IZA.

Dustmann, C., Fadlon, I., and Weiss, Y. (2011). Return migration, human capital accumulation and the brain drain. Journal of Development Economics, 95(1), 58-67. https://doi.org/10.1016/j.jdeveco.2010.04.006

Dustmann, C., Frattini, T., and Rosso, A. (2015). The effect of emigration from Poland on Polish wages. Scandinavian Journal of Economics, 117(2), 522-564.

https://doi.org/10.1111/sjoe.12102

Dustmann, C., Schönberg, U., and Stuhler, J. (2016). The impact of immigration: Why do studies reach such different results? Journal of Economic Perspectives, 30(4), 31-56. https://doi.org/10.1257/jep.30.4.31

Elsner, B. (2013). Does emigration benefit the stayers? Evidence from EU enlargement. Journal of Population Economics, 26(2), 531-553. https://doi.org/10.1007/s00148-012-04526

Eurostat. (2018). Demography and migration database. Luxembourg: Eurostat.

Eurostat. (2019a). Gini coefficient of equivalised disposable income. Luxembourg: Eurostat.

Eurostat. (2019b). International migration statistics. Luxembourg: Eurostat.

Fassio, C., Montobbio, F., and Venturini, A. (2019). Skilled migration and innovation in European industries. Research Policy, 48(3), 706-718.

https://doi.org/10.1016/j.respol.2018.11.002

Fassmann, H., and Munz, R. (1992). Patterns and trends of international migration in Western Europe. Population and Development Review, 18(3), 457. https://doi.org/10.2307/1973654

Fayissa, B., and Nsiah, C. (2010). The impact of remittances on economic growth and development in Africa. American Economist, 55(2), 92-103.

https://doi.org/10.1177/056943451005500210

Felbermayr, G. J., Hiller, S., and Sala, D. (2010). Does immigration boost per capita income? Economics Letters, 107(2), 177-179. https://doi.org/10.1016/j.econlet.2010.01.017

Giulietti, C., Guzi, M., Kahanec, M., and Zimmermann, K. F. (2013). Unemployment benefits and immigration: Evidence from the EU. Edited by Alan Barrett. International Journal of Manpower, 34(1), 24-38. https://doi.org/10.1108/01437721311319638 
Giuntella, O., Mazzonna, F., Nicodemo, C., and Vargas-Silva, C. (2019). Immigration and the reallocation of work health risks. Journal of Population Economics, 32(3), 1009-1042. https://doi.org/10.1007/s00148-018-0710-3

Glytsos, N. P. (2002). The role of migrant remittances in development: Evidence from Mediterranean countries. International Migration, 40(1), 5-26. https://doi.org/10.1111/14682435.00183

Grusky, D. (2018). The inequality reader: Contemporary and foundational readings in race, class, and gender (2nd ed.). Edited by D. B. Grusky and S. Szelényi (eds.). Abingdon, UK: Routledge. https://doi.org/10.4324/9780429494468 Bo

Guzi, M., and Kahanec, M. (2015). Socioeconomic cleavages between workers from new member states and host-country labour forces in the EU during the Great Recession. In M. Bernaciak (ed.), Market expansion and social dumping in Europe (pp. 97-121). London: Routledge.

Guzi, M., and Kahanec, M. (2019). Income inequality and the size of government: A causal analysis. IZA Discussion Paper No. 12015. Bonn: IZA.

Guzi, M., Kahanec, M., and Kurekova, L. M. (2015). What explains immigrant-native gaps in European labor markets: The role of institutions. IZA DP No. (8847). Bonn: IZA.

Guzi, M., Kahanec, M., and Kurekova, L. M. (2018). How immigration grease is affected by economic, institutional, and policy contexts: Evidence from EU labor markets. Kyklos, 71, 213-243. doi: 10.1111/kykl.12168.

Hansen, R. (2003). Migration to Europe since 1945: Its history and its lessons. Political Quarterly, 74(s1), 25-38. https://doi.org/10.1111/j.1467-923X.2003.00579.x

Harris, J., and Todaro, M. (1970). Migration, unemployment and development: A two-sector analysis. American Economic Review, 60(1), 126-142.

Heath, A., and Richards, L. (2016). Attitudes towards Immigration and Their Antecedents: Topline Results from Round 7 of the European Social Survey. European Social Survey, http://www.europeansocialsurvey.org/docs/findings/ESS7_toplines_issue_7_immigration.pdf.

Kahanec, M. (2013). Labor mobility in an enlarged European Union. In A. F. Constant and K. F. Zimmerman (eds.), International handbook on the economics of migration (pp. 137152). London: Edward Elgar Publishing.

Kahanec, M., and Guzi, M. (2017). How immigrants helped EU labor markets to adjust during the great recession. International Journal of Manpower, 38(7), 996-1015. https://doi.org/10.1108/IJM-08-2017-0205

Kahanec, M., and Pytliková, M. (2017). The economic impact of east-west migration on the European Union. Empirica, 44(3), 407-434. https://doi.org/10.1007/s10663-017-9370-x

Kahanec, M., and Zimmermann, K. (2009). International migration, ethnicity and economic inequality. In W. Salverda, B. Nolan, and T. M. Smeeding (eds.), Oxford handbook on economic inequality (pp. 455-490). Oxford: Oxford University Press. 
Kahanec, M., and Zimmermann, K. (2010). EU labor markets after post-enlargement migration. Berlin: Springer.

Kahanec, M., and Zimmermann, K. (2011). International migration, ethnicity, and economic inequality. Oxford: Oxford University Press.

https://doi.org/10.1093/oxfordhb/9780199606061.013.0019

Kahanec, M., and Zimmermann, K. (2014). How skilled immigration may improve economic equality. IZA Journal of Migration, 3(1), 2. https://doi.org/10.1186/2193-9039-3-2

Kahanec, M., Pytlikova, M., and Zimmermann, K. (2016). The free movement of workers in an enlarged European Union: Institutional underpinnings of economic adjustment. In Kahanec, M., and Zimmermann, K. (eds.), Labor migration, EU enlargement, and the Great Recession. Berlin: Springer, 1-34.

Kahanec, M., and Zimmermann, K. (2016). Labor migration, EU Enlargement, and the Great Recession. Berlin: Springer Berlin Heidelberg.

Kapur, D., and McHale, J. (2009). International migration and the world income distribution. Journal of International Development, 21(8), 1102-1110. https://doi.org/10.1002/jid.1649

Kugler, M., and Rapoport, H. (2005). Skilled migration, business networks and foreign direct investment. CESifo Working Paper No. (1455). Munich: CESifo.

Mckenzie, D., and Rapoport, H. (2007). Network effects and the dynamics of migration and inequality: Theory and evidence from Mexico. Journal of Development Economics, 84(1), 124. https://doi.org/10.1016/j.jdeveco.2006.11.003

Meardi, G. (2012). Social failures of EU enlargement : A case of workers voting with their feet. New York: Routledge.

Milanovic, B. (1987). Remittances and income distribution. Journal of Economic Studies, 14(5), 24-37. https://doi.org/10.1108/eb002657

Milanovic, B. (2011). Worlds apart: Measuring international and global inequality. Princeton, NJ: Princeton University Press.

Mountford, A. (1997). Can a brain drain be good for growth in the source economy? Journal of Development Economics, 53(2), 287-303. https://doi.org/10.1016/S0304-3878(97)00021-7

OECD. (2001). Migration policies and EU enlargement: The case of Central and Eastern Europe. Paris: OECD. https://doi.org/10.1787/9789264189324-en

Ortega, F., and Peri, G. (2009). The causes and effects of international labor mobility. Evidence from OECD Countries 1980-2005. Human Development Research Paper 2009/06. Paris: OECD.

Ottaviano, G. I. P., and Peri, G. (2012). Rethinking the effect of immigration on wages.

Journal of the European Economic Association, 10(1), 152-197.

https://doi.org/10.1111/j.1542-4774.2011.01052.x

Ottaviano, G. I. P, Peri, G., and Wright, G. C. (2013). Immigration, offshoring, and American jobs. American Economic Review, 103(5), 1925-1959. https://doi.org/10.1257/aer.103.5.1925 
Outhwaite, W. and Menjívar, C. (2019). Migration Crisis and "Brexit”. In Menjívar, C., Ruiz, M., and Ness, I. (eds.). The Oxford Handbook of Migration Crises.

Ozden, Ç., and Schiff, M. (2006). International migration, remittances, and the brain drain. Washington, DC: International Bank for Reconstruction and Development/World Bank.

Page Moch, L. (2003). Moving Europeans: Migration in Western Europe since 1650. Bloomington: Indiana University Press.

Peri, G. (2007). Immigrant's complementarities and native wages: Evidence from California. National Bureau of Economic Research Working Paper 12956. Cambridge, MA: NBER.

Peri, G. (2014). Do immigrant workers depress the wages of native workers? IZA World of Labor. https://doi.org/10.15185/izawol.42

Peri, G., and Sparber, C. (2009). Task specialization, immigration, and wages. American Economic Journal: Applied Economics, 1(3), 135-169. https://doi.org/10.1257/app.1.3.135

Perrons, D. (2009). Migration: Cities, regions and uneven development. European Urban and Regional Studies, 16(3), 219-223. https://doi.org/10.1177/0969776409104689

Picketty, T. (2014). Capital in the twenty-first century. Cambridge, MA: Harvard University Press.

Ravallion, M. (2014). Income inequality in the developing world. Science, 344(6186), 851855. https://doi.org/10.1126/science. 1251875

Recchi, E., \& Salamońska, J. (2015). Bad Times at Home, Good Times to Move? The (Not So) Changing Landscape of Intra-EU Migration. In Europe's Prolonged Crisis (pp. 124-145). Palgrave Macmillan, London.

Roy, A. S. (1997). Job displacement effects of Canadian Immigrants by Country of Origin and Occupation. International Migration Review, 31(1), 150-161.

https://doi.org/10.1177/019791839703100109

Sanderson, M. R. (2013). Does immigration have a Matthew Effect? A cross-national analysis of international migration and international income inequality, 1960-2005. Social Science Research, 42(3), 683-697. https://doi.org/10.1016/j.ssresearch.2012.12.004

Sanderson, E., and Windmeijer, F. (2016). A weak instrument F-test in linear IV models with multiple endogenous variables. Journal of Econometrics, 190(2), 212-221.

Sebastian, R., and Ulceluse, M. (Forthcoming2019). The effect of immigration on natives' task specialization: The case of Germany. International Journal of Manpower, 40(5), 939957.

Stark, O. (2004). Rethinking the brain drain. World Development, 32(1), 15-22. https://doi.org/10.1016/j.worlddev.2003.06.013

Stock, J. H., Wright, J. H., and Yogo, M. (2002). A survey of weak instruments and weak identification in generalized method of moments. Journal of Business \& Economic Statistics, 20(4), 518-529. 
Taggart, P. and Szczerbiak, A. (2018). Putting Brexit into perspective: the effect of the Eurozone and migration crises and Brexit on Euroscepticism in European states. Journal of European Public Policy, 25(8), 1194-1214.

Trenz, H. J., and Triandafyllidou, A. (2017). Complex and dynamic integration processes in Europe: intra EU mobility and international migration in times of recession. Journal of Ethnic and Migration Studies, 43(4), 546-559.

Van Mol, C., and de Valk, H. (2016). Migration and immigrants in Europe: A historical and demographic perspective. In B. Garcés-Mascareñas and R Penninx (eds.), Integration processes and policies in Europe (pp. 31-55). Cham: Springer. https://doi.org/10.1007/978-3319-21674-4_3

Wilkinson, R. G., and Pickett, K. (2009). The spirit level: Why more equal societies almost always do better. Harmondsworth: Penguin.

World Bank. (2005). Global economic prospects 2006: Economic implications of remittances and migration. Washington, DC: World Bank.

http://documents.worldbank.org/curated/en/507301468142196936/Global-economicprospects-2006-economic-implications-of-remittances-and-migration

World Bank. (2018). World development indicators. Washington, DC: World Bank.

Zaiceva, A. (2014). Post-enlargement emigration and new EU members' labor markets. IZA World of Labor. https://doi.org/10.15185/izawol.40

Zaiceva, A., and Zimmermann, K. F. (2008). Scale, diversity, and determinants of labour migration in Europe. Oxford Review, of Economic Policy, 24(3), 427-451.

https://doi.org/10.1093/oxrep/grn028

Zimmermann, K. (2005). European migration: What do we know? Oxford: Oxford University Press On demand. 


\section{Appendix}

Table A1 Variable definitions

\begin{tabular}{|c|c|c|}
\hline Variable & Source & Variable definition \\
\hline Gini index & Eurostat (ilc_di12) & $\begin{array}{l}\text { Gini coefficient for equivalised disposable } \\
\text { income (based on EU-SILC) }\end{array}$ \\
\hline Inflow & $\begin{array}{l}\text { Eurostat } \\
\text { (migr_imm1ctz) }\end{array}$ & $\begin{array}{l}\text { Immigration of citizens with foreign } \\
\text { citizenship and stateless }\end{array}$ \\
\hline Stock & Eurostat (migr_pop1ctz) & $\begin{array}{l}\text { Population with foreign citizenship and } \\
\text { stateless }\end{array}$ \\
\hline $\begin{array}{l}\text { Government } \\
\text { expenditure }\end{array}$ & $\begin{array}{l}\text { Eurostat } \\
\text { (gov_10a_main) }\end{array}$ & $\begin{array}{l}\text { Total general government expenditure (\% of } \\
\text { GDP) }\end{array}$ \\
\hline GDP per capita & Eurostat (nama_10_pc) & $\begin{array}{l}\text { Gross domestic product at market prices, } \\
\text { euro per capita, in log }\end{array}$ \\
\hline Unemployment rate & Eurostat (tsdec450) & Total unemployment rate \\
\hline Trade openness & Eurostat (nama_gdp_c) & $\begin{array}{l}\text { Sum of exports and imports (\% of GDP), in } \\
\log \end{array}$ \\
\hline Tertiary education & Eurostat (edat_lfse_03) & Population by educational attainment level \\
\hline Inflation & $\begin{array}{l}\text { Eurostat } \\
\text { (prc_hicp_manr) }\end{array}$ & $\begin{array}{l}\text { Harmonised index of consumer prices } \\
\text { (HICP), yearly averages of monthly data }\end{array}$ \\
\hline $\begin{array}{l}\text { Employment in } \\
\text { agriculture }\end{array}$ & $\begin{array}{l}\text { Eurostat (lfsa_egana, } \\
\text { lfsa_egan2) }\end{array}$ & $\begin{array}{l}\text { Employment share in agriculture (including } \\
\text { fishing, hunting and forestry) }\end{array}$ \\
\hline
\end{tabular}


Table A2 First-stage results

\begin{tabular}{|c|c|c|}
\hline Dependent variable & $\begin{array}{c}\text { Inflow } \\
(1)\end{array}$ & $\begin{array}{c}\text { Stock } \\
(2)\end{array}$ \\
\hline Inflow per 1,000 lag & $\begin{array}{l}0.20 * * \\
(0.09)\end{array}$ & $\begin{array}{c}1.57 * * * \\
(0.21)\end{array}$ \\
\hline Stock per 1,000 lag & $\begin{array}{c}-0.12 * * * \\
(0.02)\end{array}$ & $\begin{array}{c}0.49 * * * \\
(0.04)\end{array}$ \\
\hline Government expenditure & $\begin{array}{l}-0.16^{*} \\
(0.09)\end{array}$ & $\begin{array}{c}0.26 \\
(0.19)\end{array}$ \\
\hline GDP per capita & $\begin{array}{c}23.92 \\
(52.49)\end{array}$ & $\begin{array}{l}-192.58 \\
(129.46)\end{array}$ \\
\hline GDP per capita square & $\begin{array}{l}-1.36 \\
(2.74)\end{array}$ & $\begin{array}{c}7.94 \\
(6.54)\end{array}$ \\
\hline Unemployment rate & $\begin{array}{l}-0.16 \\
(0.13)\end{array}$ & $\begin{array}{c}-0.77 * * * \\
(0.20)\end{array}$ \\
\hline Trade openness & $\begin{array}{l}-4.23 \\
(4.36)\end{array}$ & $\begin{array}{c}-31.81 * * * \\
(7.82)\end{array}$ \\
\hline Tertiary education & $\begin{array}{c}0.07 \\
(0.19)\end{array}$ & $\begin{array}{l}-0.63 * \\
(0.35)\end{array}$ \\
\hline Employment in agriculture & $\begin{array}{l}-0.01 \\
(0.29)\end{array}$ & $\begin{array}{l}-0.33 \\
(0.81)\end{array}$ \\
\hline Inflation & $\begin{array}{c}0.68 * * * \\
(0.19)\end{array}$ & $\begin{array}{c}1.23 * * * \\
(0.37)\end{array}$ \\
\hline Constant & $\begin{array}{c}-49.98 \\
(247.15) \\
\end{array}$ & $\begin{array}{c}1353.94 * * \\
(640.50) \\
\end{array}$ \\
\hline Sample size & 311 & 311 \\
\hline R2/Within R2 & 0.42 & 0.43 \\
\hline F statistics & 17.97 & 98.94 \\
\hline SW F-stat & 27.37 & 87.3 \\
\hline
\end{tabular}

Source: Own calculations based on data from Eurostat.

Notes: We use past migration variables with a four-year lag as instruments. Reported are Fstatistic and Sanderson-Windmeijer (SW) first-stage F statistic. Models include year and country fixed effects. Observations are weighted by population size. $*<0.10, * *<0.05$, $* * *<$ 0.01 . 


\section{MUNI Econ Working Paper Series (since 2018)}

2021-05 Guzi, M., Kahanec, M., Ulceluse, M.M. (2021). Europe's migration experience and its effects on economic inequality. MUNI ECON Working Paper n. 2021-05. Brno: Masaryk University. https://doi.org/10.5817/WP_MUNI_ECON_2021-05

2021-04 Fazio, A., Reggiani, T., Sabatini, F. 2021. The political cost of lockdown's enforcement. MUNI ECON Working Paper n. 2021-04. Brno: Masaryk University. https://doi.org/10.5817/WP_MUNI_ECON_2021-04

2021-03 Peciar, V. Empirical investigation into market power, markups and employment. MUNI ECON Working Paper n. 2021-03. Brno: Masaryk University. https://doi.org/10.5817/WP_MUNI_ECON_2021-03

2021-02 Abraham, D., Greiner, B., Stephanides, M. 2021. On the Internet you can be anyone: An experiment on strategic avatar choice in online marketplaces. MUNI ECON Working Paper n. 2021-02. Brno: Masaryk University. https://doi.org/10.5817/WP_MUNI_ECON_2021-02

2021-01 Krčál, O., Peer, S., Staněk, R. 2021. Can time-inconsistent preferences explain hypothetical biases?. MUNI ECON Working Paper n. 2021-01. Brno: Masaryk University. https://doi.org/10.5817/WP_MUNI_ECON_2021-01

2020-04 Pelligra, V., Reggiani, T., Zizzo, D.J. 2020. Responding to (Un)Reasonable Requests by an Authority. MUNI ECON Working Paper n. 2020-04. Brno: Masaryk University. https://doi.org/10.5817/WP_MUNI_ECON_2020-04

2020-03 de Pedraza, P., Guzi, M., Tijdens, K. 2020. Life Dissatisfaction and Anxiety in COVID-19 pandemic. MUNI ECON Working Paper n. 2020-03. Brno: Masaryk University. https://doi.org/10.5817/WP_MUNI_ECON_2020-03

2020-02 de Pedraza, P., Guzi, M., Tijdens, K. 2020. Life Satisfaction of Employees, Labour Market Tightness and Matching Efficiency. MUNI ECON Working Paper n. 2020-02. Brno: Masaryk University. https://doi.org/10.5817/WP_MUNI_ECON_2020-02

2020-01 Fišar, M., Reggiani, T., Sabatini, F., Špalek, J. 2020. a. MUNI ECON Working Paper n. 2020-01. Brno: Masaryk University. https://doi.org/10.5817/WP_MUNI_ECON_2020-01

2019-08 Fišar, M., Krčál, O., Špalek, J., Staněk, R., Tremewan, J. 2019. A Competitive Audit Selection Mechanism with Incomplete Information. MUNI ECON Working Paper n. 2019-08. Brno: Masaryk University. https://doi.org/10.5817/WP_MUNI_ECON_2019-08

2019-07 Guzi, M., Huber, P., Mikula, M. 2019. Old sins cast long shadows: The Long-term impact of the resettlement of the Sudetenland on residential migration. MUNI ECON Working Paper n. 2019-07. Brno: Masaryk University. https://doi.org/10.5817/WP_MUNI_ECON_2019-07

2019-06 Mikula, M., Montag, J. 2019. Does homeownership hinder labor market activity? Evidence from housing privatization and restitution in Brno. MUNI ECON Working Paper n. 2019-06. Brno: Masaryk University. https://doi.org/10.5817/WP_MUNI_ECON_2019-06 
2019-05 Krčál, O., Staněk, R., Slanicay, M. 2019. Made for the job or by the job? A lab-in-the-field experiment with firefighters. MUNI ECON Working Paper n. 2019-05. Brno: Masaryk University. https://doi.org/10.5817/WP_MUNI_ECON_2019-05

2019-04 Bruni, L., Pelligra, V., Reggiani, T., Rizzolli, M. 2019. The Pied Piper: Prizes, Incentives, and Motivation Crowding-in. MUNI ECON Working Paper n. 2019-04. Brno: Masaryk University. https://doi.org/10.5817/WP_MUNI_ECON_2019-04

2019-03 Krčál, O., Staněk, R., Karlínová, B., Peer, S. 2019. Real consequences matters: why hypothetical biases in the valuation of time persist even in controlled lab experiments. MUNI ECON Working Paper n. 2019-03. Brno: Masaryk University. https://doi.org/10.5817/WP_MUNI_ECON_2019-03

2019-02 Corazzini, L., Cotton, C., Reggiani, T., 2019. Delegation And Coordination With Multiple Threshold Public Goods: Experimental Evidence. MUNI ECON Working Paper n. 2019-02. Brno: Masaryk University. https://doi.org/10.5817/WP_MUNI_ECON_2019-02

2019-01 Fišar, M., Krčál, O., Staněk, R., Špalek, J. 2019. The Effects of Staff-rotation in Public Administration on the Decision to Bribe or be Bribed. MUNI ECON Working Paper n. 2019-01. Brno: Masaryk University. https://doi.org/10.5817/WP_MUNI_ECON_2019-01

2018-02 Guzi, M., Kahanec, M. 2018. Income Inequality and the Size of Government: A Causal Analysis. MUNI ECON Working Paper n. 2018-02. Brno: Masaryk University. https://doi.org/10.5817/WP_MUNI_ECON_2018-02

2018-01 Geraci, A., Nardotto, M., Reggiani, T., Sabatini, F. 2018. Broadband Internet and Social Capital. MUNI ECON Working Paper n. 2018-01. Brno: Masaryk University. https://doi.org/10.5817/WP_MUNI_ECON_2018-01

ISSN electronic edition 2571-130X

MUNI ECON Working Paper Series is indexed in RePEc:

https://ideas.repec.org/s/mub/wpaper.html 